\title{
Bitki Anatomisi Çalışmalarında El Kesitleri İçin Yeni Boyama Yöntemi
}

\author{
Bahattin BOZDAĞ, Okan KOCABAŞ, Yurdanur AKYOL, Canan ÖZDEMİR
}

ÖZ

Bu çalışmada alkol ile fikse edilmiş bitki örneklerinin el kesiti ile preparat yapımında, dokuların net bir şekilde ayırt edilebilmesini sağlayan yeni bir ikili boyama yöntemi geliştirildi. Bu yeni yöntem, el kesitlerinde kullanılabilmesi ve renk farkıyla dokuları net bir şekilde ayırt etmesi bakımından pratiklik ve kesinlik sağlamaktadır. Bu yöntemde, safranin ve fast-green boyalarının belirli oranlarda karışımından oluşan ikili boya, hem monokotil
Bahattin BOZDAĞ, Okan KOCABAȘ, Canan ÖZDEMİR

Celal Bayar Üniversitesi, Fen Edebiyat Fakültesi, Biyoloji Bölümü, Muradiye, Manisa

Yurdanur AKYOL

Manisa Hasan Türek Anadolu Lisesi, Aynıali Mahallesi Kenzi Caddesi No.24 Yunusemre, Manisa

Sorumlu yazar:

Yurdanur AKYOL

Manisa Hasan Türek Anadolu Lisesi, Aynıali Mahallesi Kenzi Caddesi No.24 Yunusemre, Manisa

Tel: +902362384777

Faks: +902362380955

E-posta: yurdanur45@gmail.com

Submitted/Gönderilme: 27.02.2016 Accepted/Kabul: 07.04.2016 hem de dikotil bitki örneklerinde kullanılabilmekte ve uzun süre oda sıcaklığında bozulmadan saklanabilmektedir. Bu makalede, bu yöntemin uygulandığı çeşitli bitki örneklerine ait anatomik kesitlerin fotoğrafları çekilerek, çeşitli dokular gösterilmiştir.

Anahtar kelimeler: Bitki anatomisi, Boyama, El kesitleri, Fastgreen, Safranin.

\section{Giriş}

Bitki anatomisi laboratuvarında preparat hazırlamada kullanılan çeşitli inceleme ortamları ve bu ortamlar için kullanılan farklı boyalar bulunmaktadır. Toluidin mavisi $\mathrm{O}$ (1), laktofenol pamuk mavisi (2), laktofenol pamuk mavisi ve anilin mavisi (3), tripan mavisi ve rose bengal boyası (4), asit fuksin (5), safranin (6) ve kalkoflor (7) boyaları bunlardan sadece birkaçını oluşturmaktadır. Bu boyalar bazen tek başına bazen de iki boyanın belli oranlarda karıştırılmasıyla kullanılmaktadır. İkili boyama tekniklerinde bitkisel dokular için çoğunlukla safranin ve fast-green boyaları kullanılmaktadır (8). Safranin bazik yapılı bir boya olup başta ligninleşmiş dokular olmak üzere; kitinleşmiş, kütinleşmiş ve suberinleşmiş dokuları ve bunun yanı sıra çekirdekçik ve kromozom yapılarını boyamaktadır (9). Bunun yanında 9/1 oranında hazırlanan anilin ve astra mavisi boyaları, bazı araştırıcılar tarafından bitki dokularını boyamak için kullanılmasına rağmen, bu boyaların kullanımının bakteri ve fungal organizmalar için daha uygun olduğu düşünülmektedir (10).

Bitkisel organizmalar için kullanılan preparasyon yöntemlerinde daimi ve geçici preparat yapma yöntemleri sıklıkla kullanılmaktadır. Daimi preparat hazırlamada oldukça yaygın bir yöntem olan Algan (8)'ın parafin yöntemi kullanılmaktadır. Bu yöntem sırasıyla fiksasyon, dehidrasyon, parafin bloklara gömme, mikrotomda kesit alma, parafinden kurtarma ve boyama gibi işlem basamaklarından oluşmaktadır. Parafin yönteminde en çok safranin / fastgreen ikili boyama yöntemi tercih edilmektedir. Bu yönteme göre boyanan kesitlerin üzerine uygun bir yapıştırıcı 
yardımıyla lamel kapatılarak preparatlar hazırlanır. Oldukça maliyetli ve zaman alan bir işlem olan parafin yönteminde belirtilen basamakların birinde gerçekleşebilecek bir aksaklık çalışmanın tekrarlanmasına yol açabilmektedir. Daimi preparasyonlarda bitki materyalleri oldukça fazla kimyasal ortamından geçtiğinden bitki materyalinin kimyasal içeriğinin bir kısmı ve pigmentler kaybedilerek yapay bir görünüm elde edilmekte ve salg1 tüyleri gibi kırılgan yapılar zarar görebilmektedir. Daimi preparatlar uzun süre saklanabilir olması bakımından avantajlıydı. Fakat günümüzde geçici preparatların mikrofotoğraflarının dijital ortamda uzun süre saklanabilir olması daimi preparatlara olan ihtiyaçları da ortadan kaldırmıştır.

Geçici preparat yapımı parafin yöntemine göre çok daha kolay bir yöntemdir. Bu yönteme göre bir jilet yardımıyla alınan el kesitleri, uygun boyalarla boyanarak mikroskopta incelenebilir. Geçici preparatların boyanmasında çoğunlukla kullanılan boyalardan biri de sartur reaktifidir (11). Bu boyama yönteminde dokular tek bir rengin tonları şeklinde boyanmaktadır. Bu durum parafin yöntemi ile hazırlanan preparatlardaki dokusal kayıpların veya değişimlerin, aynı örneklerden el kesiti alınarak karşılaştırılmasına olumsuz yönde etki etmektedir.

$\mathrm{Bu}$ çalışmada el kesitlerinin incelenmesinde kolaylık sağlamak için yeni bir boyama yöntemi kullanılmıştır. Bu yöntemde kullanılan safranin ve fast-green boyaları parafin yönteminde de kullanılmaktadır. Fakat, boyaların bileşimleri ve uygulama yöntemi farklıdır. Bu yöntemi kullanmadaki amaç, parafin yöntemindeki zaman, maliyet ve oluşabilecek aksaklıkları en aza indirmek ve parafin yöntemine göre hazırlanan daimi preparatların, geçici preparatlar ile en iyi şekilde karşılaştırılmasını sağlamaktır. Ayrıca, preparasyon çalışmalarına hız kazandırmak da amaçlanmıştır.

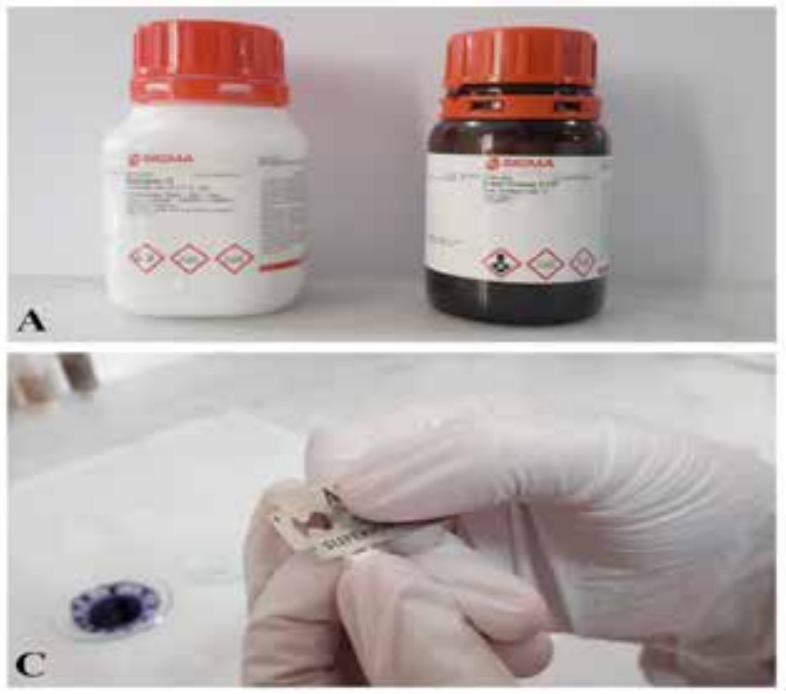

\section{Materyal ve Yöntem}

$\mathrm{Bu}$ çalışmada hazırlanan boyanın dokular üzerindeki etkisini göstermek amacıyla farklı bitki gruplarına ait; Triticum aestivum L., Cichorium pumilum Jacq., Hyparrhenia hirta (L.) Stapf, Moenchia coerulea Boiss., Scabiosa hispidula Boiss., Echium italicum L., Symphytum anatolicum Boiss. taksonları kullanılmıştır. Geçici preparatlar için geliştirilen boyanın hazırlanmasında ilk olarak kristal halde bulunan safranin $\mathrm{O}\left(\mathrm{C}_{20} \mathrm{H}_{19} \mathrm{CIN}_{4}\right)$ boyası, her $100 \mathrm{ml} \% 50$ 'lik etanol çözeltisi için $1 \mathrm{gr}$ (\%1'lik) olacak şekilde ve kristal halde bulunan fast-green FCF $\left(\mathrm{C}_{37} \mathrm{H}_{34} \mathrm{~N}_{2} \mathrm{Na}_{2} \mathrm{O}_{10} \mathrm{~S}_{3}\right)$ boyası, her $100 \mathrm{ml} \% 96$ 'llk etanol çözeltisi için $0,2 \mathrm{gr}\left(\% 0,2^{\prime}\right.$ lik) olacak şekilde tartıldı. Daha sonra bir manyetik karıştırıcı yardımıyla safranin ve fast-green boyaları, safranin için \%50'lik etanolde ve fast-green için $\% 96^{\prime} l 1 k$ etanolde homojen olacak şekilde çözdürüldü. Sonraki aşamada safranin 1 oranında fastgreen ise 9 oranında kullanılarak her iki boya birbirleriyle karıştırıldı. Bu sayede karışım el kesitleri için kullanılabilir hale geldi. Bu karışım laboratuvarda oda sıcaklığında 1520 gün süreyle özelliğini yitirmeden kullanılabilmektedir (Şekil 1A, B).

Geçici preparatlar için geliştirilen yönteme göre hazırlanacak el kesitleri ve sonrasında boyama işlemleri için aşağıda belirtilen basamaklar sırasıyla uygulandı:

- Öncelikle kesit alınacak bitki materyali, materyale zarar vermeyecek şekilde baş ve işaret parmakları arasına yerleştirilerek, çift yönlü bir jilet yardımıyla materyale göre dik açılı olacak şekilde kesildi. Saçak kökler ve uzun süre fiksatifte bekletilen bitki materyalleri gibi hassas yapılardan kesit almak için, materyalden bir parça kesilerek strafor köpük içerisine yerleştirilip, jilet yardımıyla ince bir kesit alındı (Şekil 1C, D).

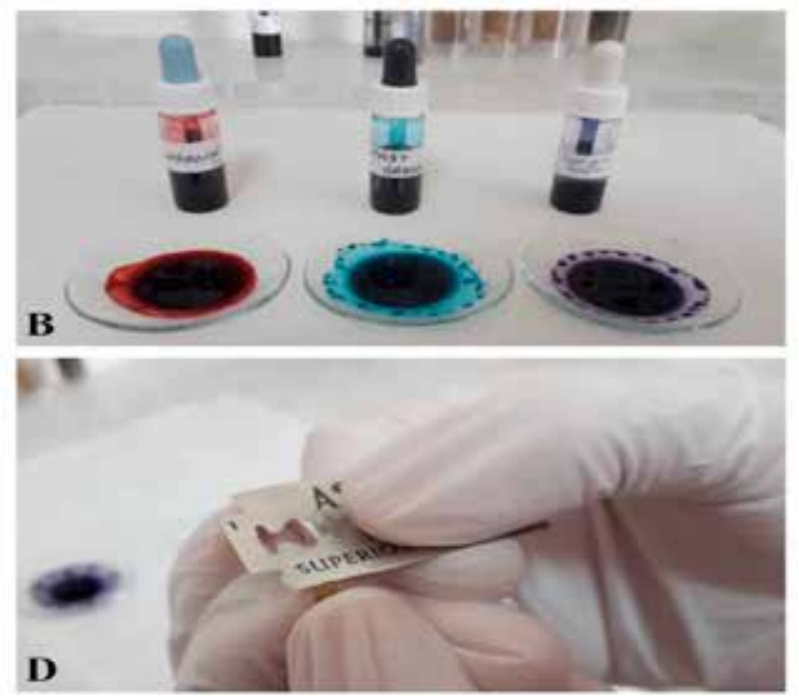

Şekil 1. Geçici preparatlar için kullanılan boyalar (A, B) ve kesit alma işlemleri (C, D) 
- $\quad$ Alınan kesitler temiz bir lam üzerine damlatılmış birkaç damla saf suyun içerisine konuldu. Daha sonra üzerine önceden hazırlanan safranin ve fast-green boya karışımı damlalık yardımıyla 1-2 damla damlatıldı. Birkaç dakika içerisinde kesitler boya karışımını hücre içine alarak boyandı. Daha sonra fazla su ve fazla boya kurutma kağıdı ile kesitlere zarar vermeden dikkatli bir biçimde emdirildi. Son olarak kesitlerin üzerine uygun bir lamel kapatıldı. Bu sayede geçici preparatlar inceleme için hazır hale gelmiş oldu.

- Hazırlanan preparatlar mikroskopta incelenerek mikrofotoğrafları çekildi.

$\mathrm{Bu}$ boyama yöntemi ile boyanmış bazı taksonlara ait olan kök, gövde, yaprak kısımlarıyla iletim demetlerinin mikrofotoğrafları bulgular bölümünde verilmiştir.

\section{Bulgular}

$\mathrm{Bu}$ çalışmada kullanılan boyalardan safranin primer yapıları ve çoğunlukla sekonder yapıları boyarken, fastgreen genellikle primer yapıları boyamaktadır. Köklerden alınan kesitlerde, safraninin en çok merkezi silindirdeki ksilem dokusunu belirgin bir biçimde boyadığı görülmüştür. Fast-green ise merkezi silindirdeki öz ve merkezi silindirin etrafındaki parankimatik yapılı korteks dokularını boyamıştır
(Şekil 2 A-D). Gövde enine kesitlerinde safranin boyasının genel olarak ksilem hücrelerini boyadığı görülmüştür. $H$. hirta türünde, iletim demetlerinin etrafındaki sklerenkimatik yapının ve korteksteki sklerenkimatik dokuların safranin ile boyandığı görülmektedir. Ayrıca, M. coerulea ve C. pumilum türlerinde bulunan kalın kutikula tabakaları da safranin sayesinde kolaylıkla ayırt edilebilmektedir. Fast-green boyasının ise parankimatik yapıda olan korteks tabakası ve floem dokularında etkili olduğu gözlenmiştir (Şekil 3A-F). Yaprak enine kesitlerinde sekonder yapı çok fazla olmadığ için genellikle mezofil tabakası tek renk boyanmaktadır. Fakat, Hyparrhenia hirta türünde olduğu gibi iletim demetlerinin etrafında gözlenen sklerenkima hücrelerinin bulunduğu yapraklarda, bu kısım safranin tarafından belirgin bir şekilde kırmızı renkte boyanmıştır (Şekil 4 A-D). $\mathrm{Bu}$ boyama yönteminin iletim demetlerindeki dokuların ayırt edilmesinde de oldukça etkili olduğu görülmüştür. Özellikle ksilem hücrelerinin ve sklerenkimatik dokuların belirginleştiği görülmektedir (Şekil 5 A-C). Bazı durumlarda dokuların mor renkte boyandığı gözlenmiştir. Bu durum \%70'lik etanol içerisinde fikse halde uzun süreli bekletilmiş ve hücre içeriğini kaybetmiş bitki materyallerinde daha fazla gözlenmektedir. Daimi preparat yapımında kullanılan parafin yönteminde de da alkol serilerinde hücresel içeriğini kaybeden örneklerde bu durum gözlenmektedir.

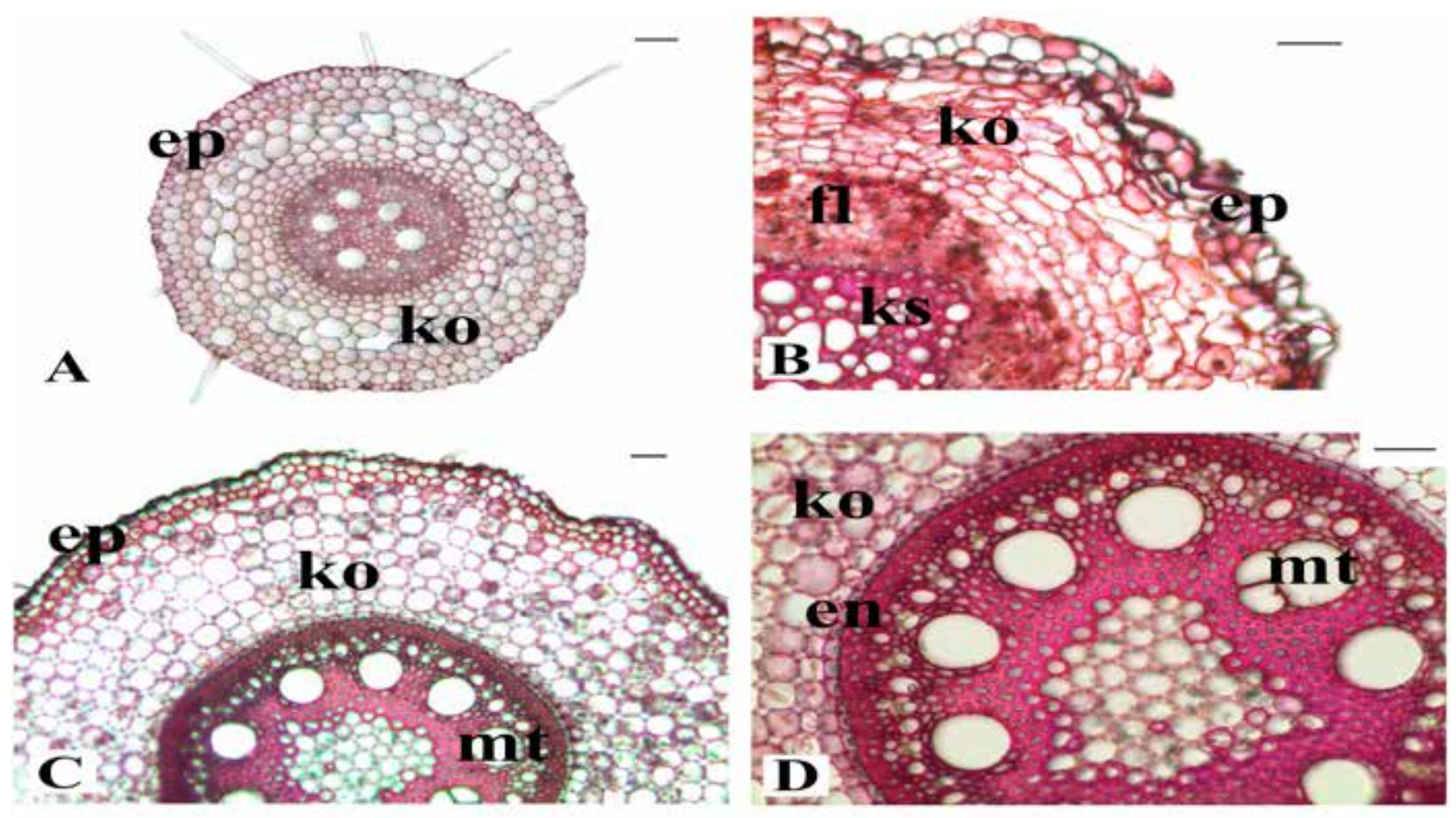

Şekil 2. Belirtilen yönteme göre boyanan T. aestivum (A), C. pumilum (B) ve H. hirta (C, D) kök enine kesitleri (Ölçek: 50 um). ep: epidermis, ko: korteks, en: endodermis, fl: floem, ks: ksilem, mt: metaksilem. 

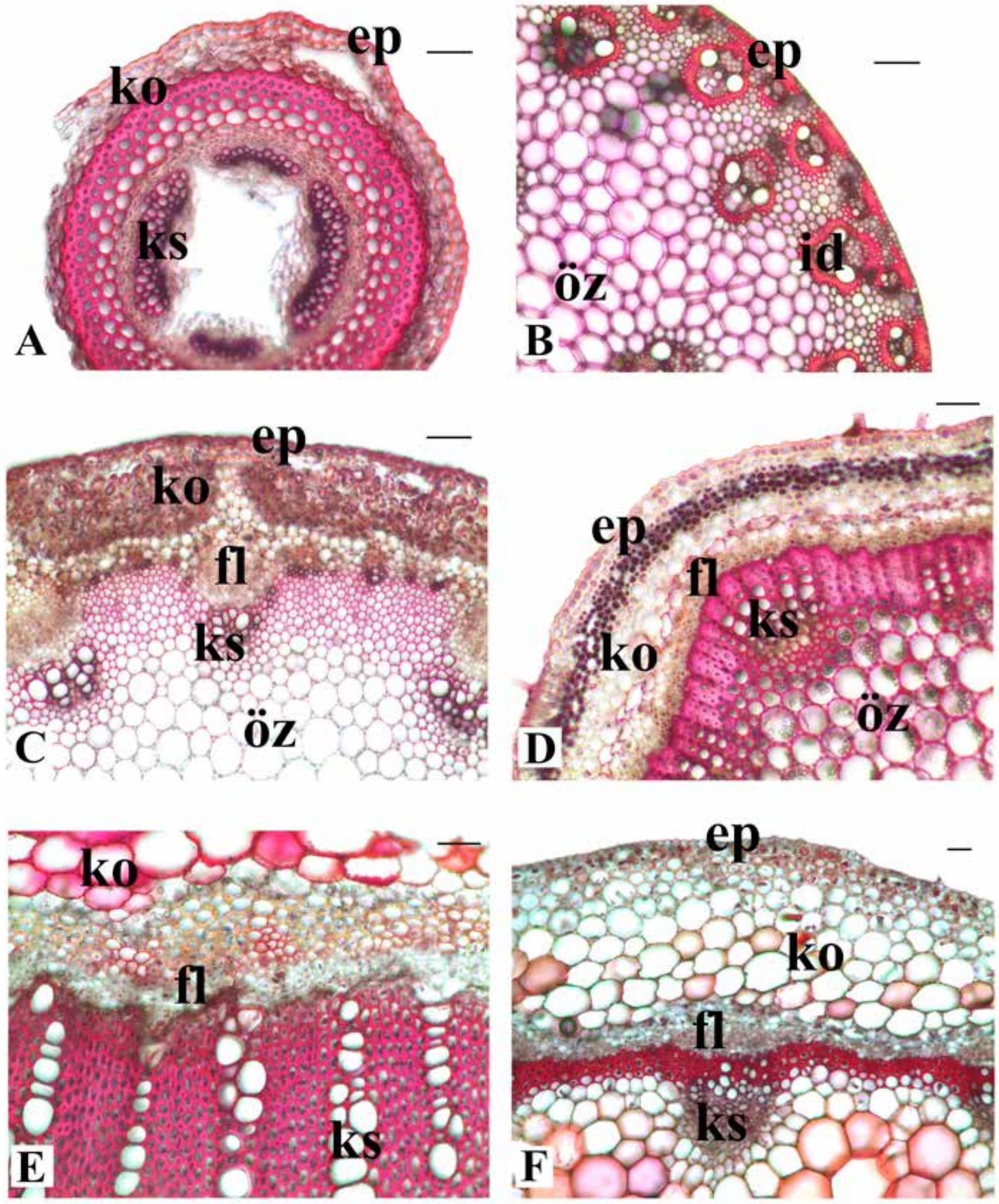

Şekil 3. Belirtilen yönteme göre boyanan M. coerulea (A), H. hirta (B), C. pumilum (C), S. hispidula (D), E. italicum (E), S. anatolicum (F) gövde enine kesitleri (Ölçek: $50 \mu \mathrm{m}$ ).

ep: epidermis, ko: korteks, id: iletim demeti, fl: floem, ks: ksilem, öz: öz bölgesi. 


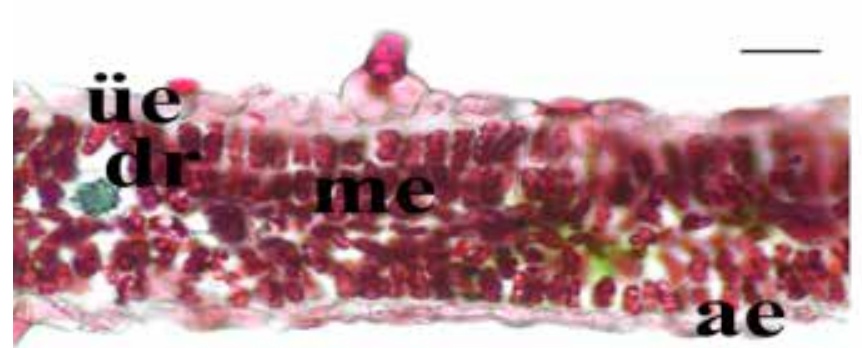

A

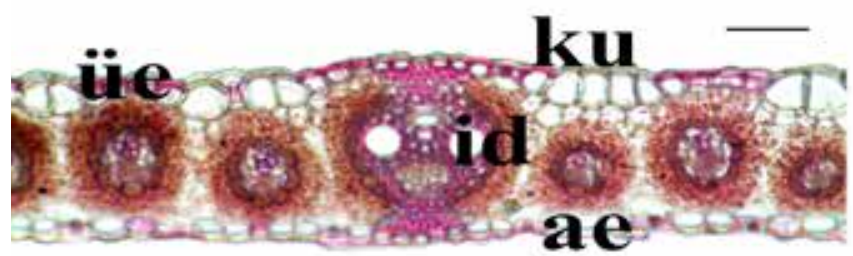

C
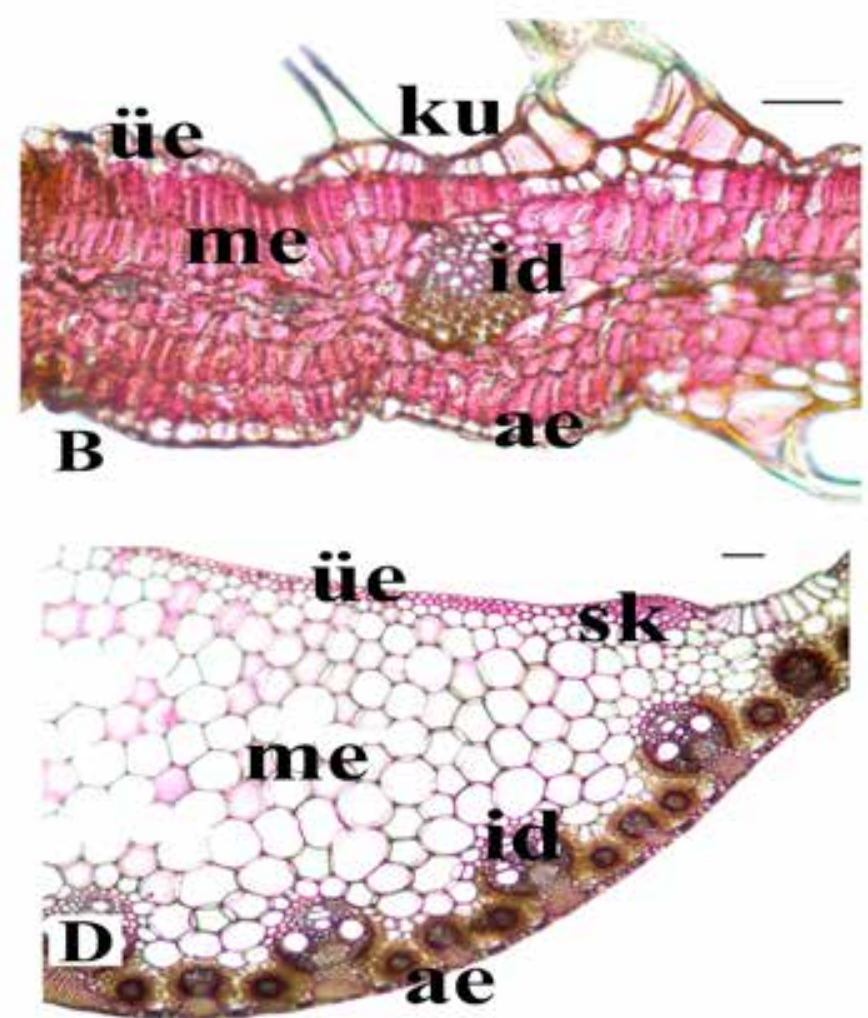

Şekil 4. Belirtilen yönteme göre boyanan S. hispidula (A), E. italicum (B), H. hirta (C) yaprak enine kesitleri ve $H$. hirta (D) yaprak ana damarı enine kesiti (Ölçek: $50 \mu \mathrm{m}$ ).

ku: kutikula, üe: üst epidermis, me: mezofil tabakası, id: iletim demeti, dr: druz kristali, sk: sklerankima, ae: alt epidermis.
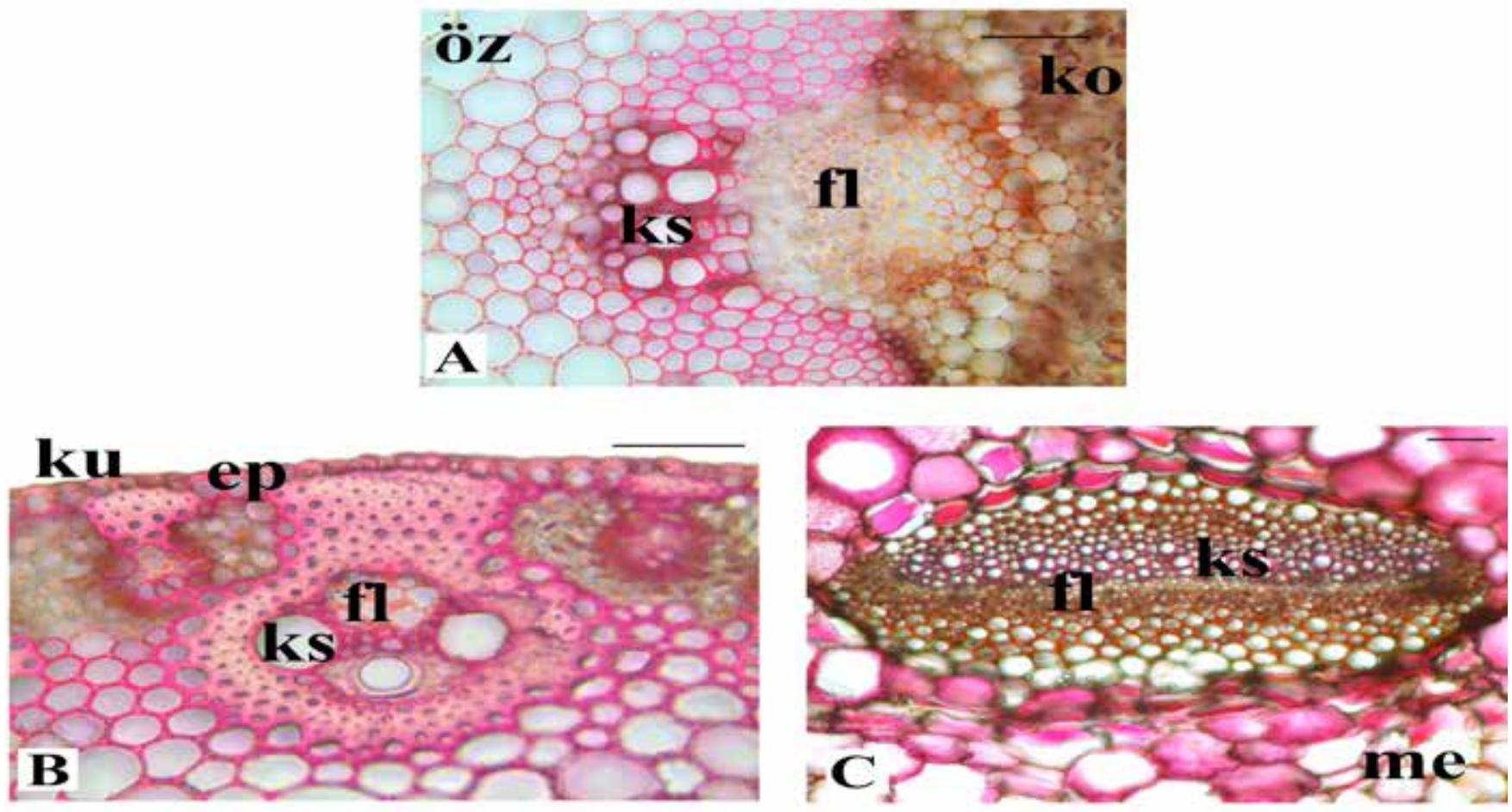

Şekil 5. Belirtilen yönteme göre boyanan C. pumilum (A), H.hirta (B), gövde iletim demetleri ve E. italicum (C) yaprak ana damarı iletim demeti (Ölçek: $50 \mu \mathrm{m}$ ).

ku: kutikula, ep: epidermis, ko: korteks, me: mezofil tabakası, fl: floem, ks: ksilem, öz: öz bölgesi. 


\section{Tartışma ve Sonuç}

Bitki anatomisi çalışmalarında doğru sonuçlar elde etmek için preparasyondaki tüm aşamalar titizlikle ele alınmalıdır. Kesit alındıktan sonra kullanılacak olan boya, incelenecek hücre ya da doku kısımlarına göre seçilmelidir. Bu çalışmada genel anlamda bitki dokularını ayırt etmek için safranin ve fast-green boyaları önceki yöntemlerden farklı bir şekilde hazırlanarak uygulanmıştır.

Safranin ve fast-green Johansen (9), Sass (12) ve Algan (8) gibi araştırmacılar tarafından geliştirilen yöntemlerle ikili kombinasyon şeklinde kullanılmıştır. Popham ve arkadaşları. (13) odunsu dokuları boyamak için safranin ve anilin mavisi boyalarını tercih etmişlerdir. Araştırmacılar safranin ile fast-green kombinasyonunun ligninleşmiş dokuları belirlemede hızlı sonuç verdiğinden daha çok bu ikisini birlikte kullanmışlardır (14). Safraninin anilin mavisi ile de kullanılabildiğini, ancak bu kombinasyonun Gymnospermler için daha uygun olduğunu belirtmişlerdir $(9,15) . \mathrm{Bu}$ çalışmada daimi preparat yapımında sıklıkla kullanılan safranin ve fast-green boyalarının tercih edilmesinin diğer bir sebebi de hem el kesitleri hem de Algan'ın (8) yöntemine göre hazırlanmış kesitleri birlikte değerlendirebilmektir.

A New Staining Method for Hand-Cut in Plant Anatomy Studies

\section{ABSTRACT}

In this study, a new double staining method that provide clearly to identify tissues in making preparations by hand-cut of plant samples were fixed with alcohol has been developed. This new method can be provides practicality and certainty in terms of
Boyaların hazırlanmasında Algan’ın (8) yöntemi uygulanmıştır. Boyaların kullanım oranlarının 9/1 olarak belirlenmesinde safranin boyasının fast-green boyasına göre dokulara daha iyi nüfuz etmesi etkili olmuştur. Johansen (9) ve Algan (8) gibi araştırmacıların uyguladıkları ikili boyamalarda, her iki boya çoğunlukla sıralı olarak yani ayrı zaman dilimlerinde farklı sürelerde kullanılmaktadır. Fakat, yeni yöntemde belirli oranlarda safranin ile fast-green karışımı kullanılmaktadır.

Parafin yöntemi gibi alkol serilerinin kullanıldığı ortamlarda bitkinin kimyasal içeriğinin kaybolması ile birlikte tüy gibi oluşumlar zarar görebilmektedir. Bu eksiklikleri gidermek için el kesiti yöntemi ile alınıp boyanan preparatlar kullanılabilir. El kesitlerinde sıklıkla kullanılan sartur reaktifi ise kesitlerde tek renk verdiğinden, dokuların net olarak ayırt edilmesi zorlaşmaktadır.

Sonuçolaraközellikle Angiosperm yapıdakibitkiörneklerinin dokularını gözlemlemek için kullanılan diğer yöntemlere göre bu yeni yöntem, zaman ve maliyet açısından daha elverişlidir. Aynı zamanda bitki anatomisi laboratuvarlarında bitki dokularını net bir şekilde ayırt etmeyi sağlar. $\mathrm{Bu}$ çalışmada hazırlanan boya kombinasyonunun pratik ve daha az maliyetli olması tercih sebeplerindendir.

distinguishing the tissues and can be used for hand-cut. In this method, double staining consist of safranin and fast green can be used in both monocotyledons and dicotyledons and can be stored at room temperature for a long time without spoiling. Photographs of the anatomical sections is used this method was taken and tissues was demonstrated.

Keywords: Plant anatomy, Staining, Hand-cut, Fast-green, Safranin

\section{KAYNAKLAR}

1. Ghemawat MS. Polychromatic staining with toluidine blue $\mathrm{O}$ for studying the host-parasite relationships in wheat leaves of Erysiphe graminis f. sp. tritici. Physiol Plant Pathol 1977; 11: 251-3.

2. Heath MC. Light and electron microscope studies of the interactions of host and non-host plants with cowpea rustUromyces phaseoli var. vignae. Physiol Plant Pathol 1974; 4: 403-14.

3. Shipton WA, Brown JF. A whole-leaf clearing and staining technique to demonstrate hostpathogen relationships of wheat stem rust. Phytopathology 1962; 52: 1313.

4. Saha DC, Jackson MA, Johnson-Cicalese JM. A rapid staining method for detection of Endophytic fungi in turf and forage grasses. Phytopathology 1988; 78: 237-9.
5. McBride MC. A method of demonstrating rust hyphae and haustoria in unsectioned leaf tissue. Am J Bot 1936; 23: 686-8.

6. Bandoni RJ. Safranin $\mathrm{O}$ as a rapid nuclear stain for fungi. Mycologia 1979; 11: 873-4.

7. Trese AT, Loschke DC. High contrast resolution of mycelia of pathogenic fungi in corn tissue after staining with calcofluor and destaining with cellulose. Phytopatology 1990; 80: 196200 .

8. Algan G. Bitkisel Dokular İçin Mikroteknik. Firat Üni Fen Ed Fak Yay Bot No:1. İstanbul. 1981.

9. Johansen DA. Plant microtechnique. McGraw-Hill Book Co., Inc., New York and London. 1940, pp.553.

10. Yeung ECT, Stasolla C, Sumner MJ, Huang BQ. Plant Microtechniques and Protocols, Springer International 
Publishing (EBook). Switzerland. 2015.

11. Baytop A. Bitkisel Drogların Anatomik Yapısı. İstanbul Üni Yay 6. Baskı No: 32. İstanbul. 1981.

12. Sass J. Botanical Microtechnique. Third Edition. Iowa State University Press, Iowa. 1958.

13. Popham RA, Johnson TJ, Chan AP. Safranin and anilin blue with Delafield's hematoxylin for staining cell walls in shoot apexes. Stain Tech 1948; 23:185-90.

14. Balatinecz JJ, Kennedy RW. Maturation of ray parenchyma cells in pine. Forest Prod J 1967; 17: 57-64.

15. Jensen WA. Botanical Histochemistry: Principles and Practice. Freeman, San Francisco. 1962. 